\title{
The dammed river dolphins of Brazil: impacts and conservation
}

\author{
Claryana C. Araúo and John Y. Wang
}

\begin{abstract}
A major threat to river dolphins in Brazil is habitat loss and fragmentation as a result of the construction of hydroelectric dams. We examine the degree of overlap between the distributions of two river dolphin species (boto Inia geoffrensis and tucuxi Sotalia fluviatilis) and hydroelectric projects and provide an initial quantification of impacts. The locations of dams were overlaid onto a map of the known distributions of the dolphins. Two types of impacts were evaluated: population fragmentation and effects on prey. For each of these a binary score (for absence or presence) was assigned for each dam. The sum of all impact scores for each dam, in each of the three watersheds in which dolphins are found, including realized and potential impacts, was calculated as the impact index. Thirteen dams affect the distribution of I. geoffrensis (as could a further three dams under construction and seven planned), and three dams affect $S$. fluviatilis (as could three under construction and two planned). Overall, the impact index was higher for I. geoffrensis than for S. fluviatilis. The Araguaia-Tocantins and North Atlantic watersheds have higher impact index values than the Amazon watershed. Although some impacts of damming could not be considered in this study, our approach was a rapid initial risk assessment that provided an overall understanding of how river dolphins are and may be affected by hydroelectric projects in Brazil. Our method may be applicable to other freshwater cetaceans and species facing similar threats when information about impacts is incomplete.
\end{abstract}

Keywords Brazil, conservation, distribution, human impact, hydroelectric dams, Inia geoffrensis, Sotalia fluviatilis

\section{Introduction}

T $\mathrm{n}$ Brazil there are two species of freshwater cetaceans: the boto or Amazon River dolphin Inia geoffrensis (family Iniidae) and the tucuxi Sotalia fluviatilis (family

Claryana C. Araújo* (Corresponding author) Applied Ecology and Conservation Lab, Federal University of Goiás, UFG, Goiânia, Goiás, Brazil, 74001-970. E-mail araujoclaryana@gmail.com

JoHN Y. WANG $\dagger$ CetAsia Research Group Ltd, Thornhill, Ontario L4J-7X1, Canada

*Also at: Projeto Boto Araguaia, Goiânia, Goiás, Brazil

$\dagger$ Also at: Department of Biology, Trent University, Peterborough, Ontario, Canada

Received 7 February 2014. Revision requested 5 April 2014.

Accepted 29 April 2014. First published online 24 July 2014.
Delphinidae; Best \& da Silva, 1993; da Silva \& Best, 1996). A new species of Inia, in the Araguaia River, has been proposed (Hrbek et al., 2014) but the taxonomy has not been adopted by the Society of Marine Mammalogy (Committee on Taxonomy, 2014). Thus we conservatively refer to the botos of the Araguaia River as Inia geoffrensis.

I. geoffrensis and S. fluviatilis have different morphologies and ecologies but are sympatric in parts of their ranges (da Silva \& Martin, 2010). In Brazil I. geoffrensis occurs in rivers and lakes of the Amazon, in the Araguaia-Tocantins and North Atlantic watersheds. The species also occurs in Venezuela (Orinoco watershed), Colombia (Orinoco and Amazon watersheds), Ecuador, Peru and Bolivia (Amazon watershed; but the dolphins upstream of the Teotônio rapids of the Madeira River appear to comprise a distinct species, Inia boliviensis, which was recently recognized by the Committee on Taxonomy, 2014). S. fluviatilis has a more restricted distribution, occurring mainly in the Amazon River basin drainage (Brazil, Colombia, Ecuador and Peru) and also in the North Atlantic watershed in Brazil (Lima et al., 2010; da Silva 2011a), with small and shallow rivers and rapids apparently being barriers to its movement. The occurrence of this species in the Araguaia-Tocantins watershed in central Brazil is limited to the lower reaches of the Tocantins River, downstream of the Tucuruí dam (da Silva et al., 2010; da Silva, 2011a).

In Brazil some of the main threats to these species are accidental and intentional killing. Accidental killing is usually related to entanglement in fishing gear and occurs throughout the species' distributions (da Silva \& Martin, 2010). Intentional killing is mainly of $I$. geoffrensis. In the central Amazon this species has been intentionally killed as bait for catfish fisheries and to reduce perceived competition for fisheries resources or out of fear and spite (da Silva \& Martin, 2010; Mintzer et al., 2013). In the AraguaiaTocantins river basin dolphins have been killed by fishermen because they are perceived as competition for fish resources (to our knowledge, not for bait); some individuals have been observed with gunshot wounds (Araújo \& Wang, 2012; Araújo \& da Silva, 2014). Another major threat to these two species of river dolphins in Brazil is habitat loss and fragmentation caused by hydroelectric dams. For example, the Tucuruí dam has isolated I. geoffrensis of the AraguaiaTocantins river basin from conspecifics in the Amazon River basin (da Silva \& Martin, 2010; Araújo \& Wang, 2012).

Brazil currently has $>150$ hydroelectric dams of over $30 \mathrm{MW}$ and $>300$ small hydroelectric dams (ANEEL, 2008). Circa $70 \%$ of Brazil's electricity is from hydroelectric 


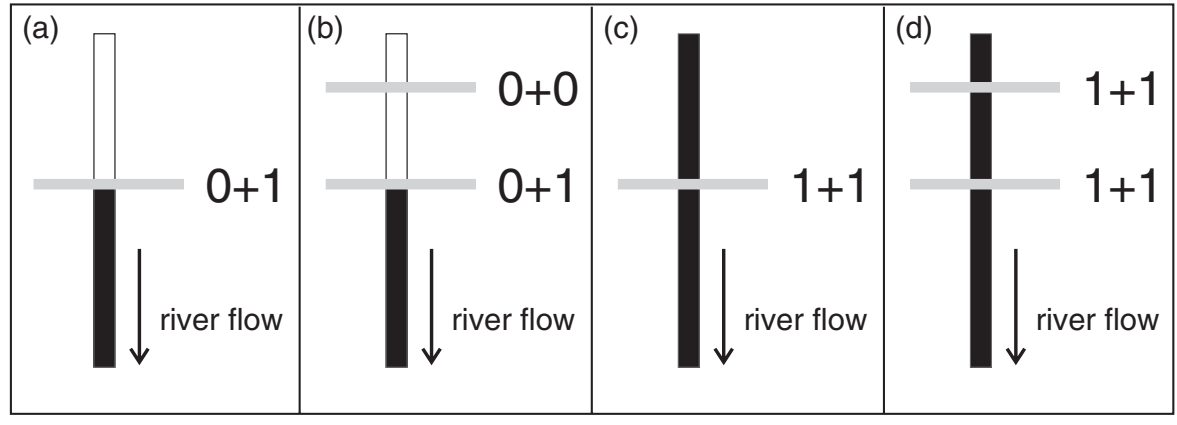

FIG. 1 Schematic representation of the four potential locations of hydroelectric dams relative to the distribution of dolphins, and their impact scores (see text for details). Black vertical bars represent presence of dolphins and white vertical bars their absence. Horizontal bars represent dams on the river. The first and second numbers represent the impact scores for population fragmentation and effects on prey, respectively. generation and this is likely to increase with the construction of large hydroelectric complexes to supply Brazil's developing economy. The controversial construction of the Belo Monte dam on the Xingu River will result in the third largest hydroelectric dam after the Brazil-Paraguay Itaipu dam in southern Brazil and the Three Gorges in China (MME, 2007). Most of the existing dams and eight dams under construction in Brazil also overlap with important biodiversity hotspots (Myers et al., 2000; MME, 2007), including the habitat of I. geoffrensis and S. fluviatilis.

The need for a better understanding of the impacts of hydroelectric dams on river dolphins and the establishment of a register of current and proposed dams has been highlighted as a priority action for river dolphins in South America (IWC, 2000; Trujillo et al., 2010). Despite the large number of hydroelectric projects that are known to affect river dolphins in Brazil, there has been no evaluation of the potential overlap between these projects and river dolphins. We therefore examine the degree of overlap between the distributions of river dolphins and hydroelectric projects and quantify the impacts of this threat to river dolphins for each watershed in Brazil.

\section{Methods}

\section{Distribution}

The locations of hydroelectric dams in Brazil were plotted onto a map of the known distributions of the two species of river dolphins. The locations of all existing dams and those under construction were obtained from official government reports (ANEEL, 2008; MME, 2013) and checked using the satellite images available on Google Earth v. 7.1.2.2041 (Google, Mountain View, USA). For proposed dams, locations were based on the latest government report (MME, 2013). For the distributions of I. geoffrensis and S. fluviatilis we began with the information available on the IUCN Red List of Threatened Species (IUCN, 2013). However, the distribution maps for both species contained several errors. These were corrected and updated with other available information (Best \& da Silva, 1993; da Silva \& Best, 1996; Siciliano et al., 2008; da Silva \& Martin, 2010; da Silva et al., 2010; Lima et al., 2010; da Silva, 2011a,b; da Silva et al., 2013).

Each watershed was evaluated (as suggested by Smith et al., 2000, in an impact assessment for other river dolphin species). In studies of South American river dolphins the distribution of I. geoffrensis is presented as only occurring in the Amazon watershed, with the Araguaia-Tocantins watershed not being treated separately from the Amazon. The Araguaia-Tocantins watershed is, however, distinct because its rivers flow into the delta into which the Amazon drains and are not tributaries of the Amazon (Lima et al., 2004; ANA, 2006). Additionally, there is another small watershed, the North Atlantic, the source of which is the Araguari River (Magrini et al., 200o), in the state of Amapá in northern Brazil (ANA, 2006). Recent records have shown that I. geoffrensis also occurs in this watershed (da Silva et al., 2013). We thus consider three watersheds in our evaluation of the impacts of dams on I. geoffrensis.

Because the distribution of $S$. fluviatilis is primarily in the Amazon River system and North Atlantic watershed, and occurs only in the mouth of the Tocantins River, we only considered the impacts of hydroelectric projects on S. fluviatilis in the Amazon and North Atlantic watersheds.

\section{Scoring of impacts}

There are several potential impacts of dams on aquatic life but most impacts (such as contamination and disease outbreak) are difficult to quantify and poorly known. We therefore limited our evaluation to two types of impacts: population fragmentation and effects on prey (Reeves \& Leatherwood, 1994). For each dam (existing, under construction and planned), the absence or presence of each impact is scored o or 1, respectively, following one of four different possibilities (Fig. 1). If a dam is located upstream of the limit of a species' distribution, population fragmentation is scored absent but the impact on prey is scored present (as the dam can still affect fish populations, for example through fragmentation and changes in abundance and 
distribution; Fig. 1a). In the case where another dam is upstream of the first dam (on the limit of the species' distribution), we score absent for both impacts and do not consider such dams further in our analysis (Fig. 1b). If a dam is located within the species' distribution both impacts are scored present (Fig. 1c). When another dam is located within the species' distribution, both impacts are also scored present (Fig. 1d), even though there is likely to be a greater level of impact with the additional dam. As a result, each dam can have an impact score of 0,1 or 2 .

An overall impact index for each watershed was calculated as the sum of all impact scores for each dam in the watershed, including the realized and potential impacts (realized impacts refer to existing dams and those under construction, and potential impacts refer to planned dams). Because the three watersheds vary greatly in area, the impact index for each watershed is also rescaled by its proportional area in relation to the Amazon watershed.

\section{Results}

\section{Distribution}

We attempted to compile the most recent and accurate information on the distributions of the two dolphin species (Fig. 2), with a particular focus on areas with dams. The upstream limit of I. geoffrensis is still poorly known in many rivers but in most cases this did not affect our assessment of impacts. We made some corrections to the distribution map for this species in the Araguaia River as it does not occur in all the upstream reaches (CCA, unpubl. data) but more information is still needed for this species. The occurrence of I. geoffrensis in the estuary area of Marajó Island and other small rivers of this island and adjacent coastal waters has now been documented and sightings in the extreme north of the North Atlantic watershed have also been reported (Siciliano et al., 2008; Costa et al., 2013).

Information on S. fluviatilis was also updated, including records of this species in the North Atlantic watershed (Lima et al., 2010). Corrections to the distribution map of this species were also made, reducing the known upstream range in the Xingu and Tapajós Rivers (da Silva et al., 2010). In the area of Marajó Island the two species of Sotalia are potentially sympatric (da Silva et al., 2010). Although S. fluviatilis has been reported from this area the downstream limits and distributional boundaries of this species (and of S. guianensis) are uncertain.

\section{Scoring of impacts}

A total of 13 existing dams, three under construction and seven planned lie within the distribution of I. geoffrensis (Fig. 2a). Fewer dams lie within the distribution of
S. fluviatilis: three existing, three under construction and two planned (Fig. 2b). The values of realized and potential impact scores and impact indices for the two species are presented in Table 1. Of the 23 dams (including planned dams) that overlap or adjoin the distribution of I. geoffrensis, 11 are located in the Araguaia-Tocantins watershed, 10 in the Amazon watershed and two in the North Atlantic watershed. Of the eight dams (including planned dams) that overlap or adjoin the distribution of $S$. fluviatilis, one is in the Araguaia-Tocantins watershed, five in the Amazon watershed and two in the North Atlantic watershed. The dams affecting the two species, and the impact scores and other information are in Table 2.

The Araguaia-Tocantins watershed had the highest impact index for $I$. geoffrensis because all existing and planned dams received a maximum score for the impact of both population fragmentation and effects on prey. The Amazon watershed had a lower impact index: it has one fewer dam than the Araguaia-Tocantins watershed and not all dams received a maximum score. The North-Atlantic watershed had the lowest impact index, with only two dams in this watershed (Table 1). However, when the impact indices were scaled to account for differences in area, the North Atlantic watershed had the highest impact index and the Amazon watershed the lowest (Table 1).

For S. fluviatilis most of the dams did not receive a maximum impact score (these dams mostly affected this species through impacts on prey). Only one dam under construction and one planned received the maximum impact score. When the impact indices were scaled to account for watershed area, the North Atlantic watershed had a high impact index compared to the Amazon watershed (Table 1).

\section{Discussion}

The distributions of the two species of river dolphins in Brazil are known on a broad scale but detailed information is poor for some regions (da Silva \& Martin, 2010). Although the distribution maps provided here are more detailed and current than those available in the IUCN Red List assessments, some areas of occurrence are still poorly documented.

For I. geoffrensis, sightings have been confirmed in the extreme north of the North Atlantic watershed (in the Cassiporé River; Siciliano et al., 2008). However, the full range of its occurrence along the coast of this area needs to be better known. Although strandings have been documented as far as the north coast of Marajó Island (Costa et al., 2013) we only included information from confirmed sightings. Information from strandings is not a reliable source of occurrence as carcasses can be washed downstream and moved by currents to areas far from their normal 

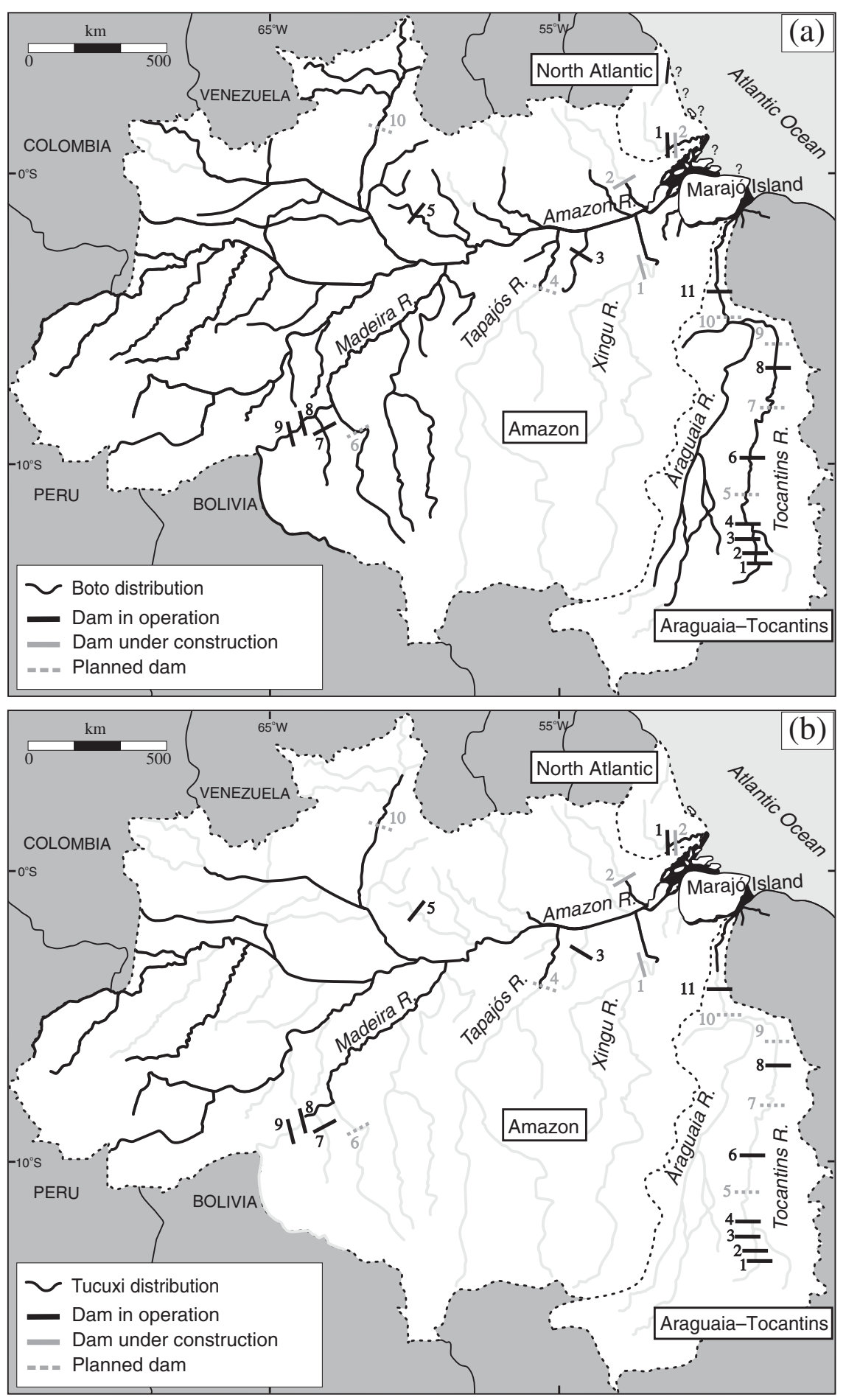

FIG. 2 (a) The distribution of Inia geoffrensis (question marks indicate unconfirmed occurrence) and (b) Sotalia fluviatilis and the locations of hydroelectric dams in central Brazil. The three watersheds (North Atlantic, Amazon and Araguaia-Tocantins) are indicated by dashed lines. The names of the numbered dams are provided in Table 2. occurrence. This may happen in particular in areas of strong currents and/or water flow, such as around Marajó Island and adjacent waters.

In the Amazon delta, including around Marajó Island, S. fluviatilis may be sympatric with $S$. guianensis but more information on these species is required for this area. As more research is conducted the distribution maps for these species will be further refined. This may not, however, greatly affect the relative values of the impact index for each watershed.
Hydroelectric dams in Brazil overlap considerably with the distribution of river dolphins. This overlap is not evenly distributed, with some areas having many more dams and thus a higher impact index. Both the Araguaia-Tocantins and North Atlantic watersheds have high rescaled impact indexes. Even though the North Atlantic watershed has only two dams its small size greatly increases the overall impact of the dams, which are affecting two species of river dolphins. The dams in the Araguaia-Tocantins watershed 
TABLE 1 Impact scores and impact indexes (see text for details) for the boto Inia geoffrensis and tucuxi Sotalia fluviatilis in each watershed (Fig. 1).

\begin{tabular}{|c|c|c|c|c|}
\hline \multirow[b]{2}{*}{ Watersheds } & \multicolumn{2}{|c|}{ Impact scores } & \multirow{2}{*}{$\begin{array}{l}\text { Impact } \\
\text { index }\end{array}$} & \multirow{2}{*}{$\begin{array}{l}\text { Rescaled } \\
\text { impact } \\
\text { index }\end{array}$} \\
\hline & Realized & Potential & & \\
\hline \multicolumn{5}{|l|}{ Boto } \\
\hline Araguaia-Tocantins & 14 & 8 & 22 & 110 \\
\hline Amazon & 12 & 5 & 17 & 17 \\
\hline North Atlantic & 3 & & 3 & 156 \\
\hline \multicolumn{5}{|l|}{ Tucuxi } \\
\hline Amazon & 3 & 3 & 6 & 6 \\
\hline North Atlantic & 3 & & 3 & 156 \\
\hline
\end{tabular}

have the greatest impact on I. geoffrensis; only the Tucurui dam affects $S$. fluviatilis. All the dams in the AraguaiaTocantins watershed are on the Tocantins River. As a result, the seriousness of the impacts of dams on the Tocantins River would appear diluted and lessened by the lack of dams on the Araguaia River (dams have been proposed for this river but have not yet been approved).

In the Tocantins River I. geoffrensis is fragmented into eight groups and if all planned dams are built this will further fragment this species into 12 separate units (Araújo \& Wang, 2012). Other I. geoffrensis populations have also been fragmented, by the Balbina Dam (number 5 on Fig. 2) on the Uatumã River and Santo Antônio Dam (8 on Fig. 2) on the Madeira River. The effects of fragmentation on riverine cetaceans are of great concern (Smith et al., 2000; Turvey et al., 2007), as for other aquatic species (Agostinho et al., 2008). In the Ganges river system in Nepal and India at least 42 water development projects, including high dams for power generation and barrages for flood control, irrigation and/or navigation purposes, have affected the rivers in which dolphins occur or once occurred (Smith et al., 2000). As a result of the effects of dams and barrages some isolated groups of the South Asian river dolphin Platanista gangetica in Nepal and the Karnaphuli system in Bangladesh may have disappeared or been drastically reduced (Reeves et al., 2000).

As expected there is a higher impact index for I. geoffrensis than for S. fluviatilis because of the former's wider distribution. Moreover, S. fluviatilis does not occur throughout the Araguaia-Tocantins watershed, which decreases the impact index for this species as most of the dams are located in this watershed. Despite the high impact of dams on the Tocantins River the dolphins of this river are usually overlooked. Only recently has $I$. geoffrensis in this area received more scientific attention (e.g. Araújo \& Wang, 2012; Araújo \& da Silva, 2014; Hrbek et al., 2014).

In the Tocantins River some short-term changes in the distribution of I. geoffrensis have been observed (e.g. the highest density of dolphins is now found just downstream of dams). This is probably a result of changes in prey distribution (Araújo \& Wang, 2012) and hydrology resulting from the erection of the physical barriers. This downstream area has a high concentration of fish and dolphins are often seen feeding in this stretch of river. The dolphins may be exposed to less human disturbance downstream of dams because of restriction zones in which human activities are prohibited for safety concerns, which may be beneficial in the short-term. The restriction zones vary but often extend 500-1,000 m downstream of a dam. However, some dams are built close to cities, and inadequate enforcement of the restriction zones, where fish and dolphins often concentrate, may expose the dolphins to human activities such as fishing and boat traffic. Observations of illegal fishing inside the restriction zone are more common at those dams that are built close to human settlements. This proximity may facilitate access to restriction zones for fishermen, and penalties may be inadequate to deter illegal activities (CCA, unpubl. data). It is therefore important that restriction zones are strictly enforced so that at least in these areas dolphins have protection against human activities. Another beneficial measure would be to expand the restriction zones to provide further protection, especially at those dams built close to human population centres. The extent of this expansion would be case-specific and would probably depend on dolphin densities downstream of the dam, proximity of human settlements and the ability to enforce the expanded area. Therefore, more detailed information would be needed for each case to better direct the establishment of restriction zones that would also adequately protect dolphins.

Dams that are built at the upstream limit of the distribution of a species do not fragment the population. However, these dams may alter the behaviour of and use of an area by $I$. geoffrensis more than previously thought as short-term changes have already been observed. This species could be displaced from areas of previous occurrence and possibly attracted to areas closer to the dam because of the changes in the distribution of prey, and consequently become more vulnerable when concentrated in these areas.

New proposals for dams should consider how to minimize the fragmentation and isolation of dolphins. In cases where a dam is proposed downstream of an existing dam and within a dolphin's distribution, changing to an upstream location could have less impact. For example, in the North Atlantic watershed the existing dam (number 1 on Fig. 2) in the Araguari River was built above the upstream limit of the distribution of both dolphin species. The dam that is under construction ( 2 on Fig. 2) will be downstream of the existing dam and will fragment and isolate both river dolphin species between the two dams. Placing the new dam upstream of the existing dam would have less impact.

Although dams may provide some immediate short-term benefits, such as concentrating fish and thus facilitating foraging, longer-term impacts are still unclear and may be of 
TABLE 2 The hydroelectric dams affecting the boto and tucuxi in Brazil, by watershed, with information on construction and operation dates, capacity, distance to the nearest downstream town, and impact scores (see text for details) for the two species. See Fig. 2 for the numbered locations of the dams.

\begin{tabular}{|c|c|c|c|c|c|c|c|}
\hline \multirow[b]{2}{*}{ Dam (by watershed) } & \multirow[b]{2}{*}{ River } & \multicolumn{2}{|l|}{ Status } & \multirow{2}{*}{$\begin{array}{l}\text { Capacity } \\
(\mathrm{MW})\end{array}$} & \multirow{2}{*}{$\begin{array}{l}\text { Distance to } \\
\text { settlement }(\mathrm{km})\end{array}$} & \multicolumn{2}{|c|}{ Impact score } \\
\hline & & Construction began & Operation began & & & Boto & Tucuxi \\
\hline \multicolumn{8}{|l|}{ Araguaia-Tocantins } \\
\hline 1. Serra da Mesa & Tocantins & 1986 & 1998 & $1,418.40$ & 52.1 & 2 & \\
\hline 2. Cana Brava & Tocantins & 1999 & 2002 & 450 & 74.6 & 2 & \\
\hline 3. São Salvador & Tocantins & 2007 & 2009 & 243 & 8.45 & 2 & \\
\hline 4. Peixe-Angical & Tocantins & 2002 & 2006 & 498.75 & 32.7 & 2 & \\
\hline 5. Ipueiras & Tocantins & Planned & Planned & 480 & & 2 & \\
\hline 6. Luis Eduardo Magalhães & Tocantins & 1998 & 2001 & 902.5 & 24 & 2 & \\
\hline 7. Tupirantins & Tocantins & Planned & Planned & 620 & & 2 & \\
\hline 8. Estreito & Tocantins & 2007 & 2011 & 1,087 & 3 & 2 & \\
\hline 9. Serra Quebrada & Tocantins & Planned & Planned & 1,328 & & 2 & \\
\hline 10. Marabá & Tocantins & Planned & Planned & 2,160 & & 2 & \\
\hline 11. Tucuruí & Tocantins & 1975 & 1984 & 8,370 & 7.6 & 2 & 1 \\
\hline \multicolumn{8}{|l|}{ Amazon } \\
\hline 1. Belo Monte & Xingu & 2011 & Planned & 11,233 & 107 & 1 & 1 \\
\hline 2. Santo Antônio do Jari & Jari & 2011 & Planned & 373.4 & 35.8 & 1 & 1 \\
\hline 3. Curuá-Una & Curuá-Una & 1968 & 1977 & 30 & 144 & 2 & \\
\hline 4. São Luiz do Tapajós & Tapajós & Planned & Planned & 6,133 & & 1 & 1 \\
\hline 5. Balbina & Uatumã & 1985 & 1988 & 250 & 2.5 & 2 & \\
\hline 6. Tabajara & Machado & Planned & Planned & 350 & & 2 & 1 \\
\hline 7. Samuel & Jamari & 1982 & 1989 & 216 & 99 & 2 & \\
\hline 8. Santo Antônio & Madeira & 2008 & 2012 & $3,150.4$ & 5.6 & 2 & 1 \\
\hline 9. Jirau & Madeira & 2009 & 2013 & 3,750 & 35.6 & 2 & \\
\hline 10. Bem Querer & Branco & Planned & Planned & 709 & & 2 & 2 \\
\hline \multicolumn{8}{|l|}{ North Atlantic } \\
\hline 1. Coaracy Nunes & Araguari & 1970 & 1975 & 78 & 12.6 & 1 & 1 \\
\hline 2. Ferreira Gomes & Araguari & 2011 & Planned & 252 & 1.5 & 2 & 2 \\
\hline
\end{tabular}

greater concern. There is no information on possible accumulation of contaminants and pollutants, disease outbreaks or how changes in water flow and sedimentation could affect the dolphins. Furthermore, in some cases the dolphins' range may contract (e.g. in some areas there seems to be an avoidance of the deep, flooded reservoirs upstream of dams as the density and richness of fish in those areas appear to be lower; Agostinho et al., 2008). Even though the detection of these impacts may be possible, quantifying the level of some of these effects, which may synergize with localized threats, will be difficult.

Isolation and fragmentation are the most obvious impacts of hydroelectric developments; subsequent demographic and genetic consequences will only be perceived in the long term. However, it is known that small and isolated populations have a higher susceptibility to stochastic events that may increase their vulnerability to local extinctions (Caughley, 1994). Impacts on prey will also affect dolphins, through reductions in numbers or changes in distribution. The distribution of river dolphins appears to be mainly driven by prey availability (Martin et al., 2004; Araújo \& da Silva, 2014). As shown by our evaluation, river dolphins in
Brazil are significantly affected by fragmentation and isolation and, even when not fragmented, some populations are affected by the impact of the dams on their prey. Moreover, hydroelectric developments reduce the environmental complexity that makes rivers suitable for abundant and diverse prey for dolphins (Reeves et al., 2000). Water development projects have significant and far-reaching consequences but little is known about their level of impact and the long-term effects on riverine wildlife, including freshwater cetaceans (Reeves \& Smith, 1999; Reeves et al., 2000).

Our evaluation of impacts was conservative. However, although some impacts may have been underestimated or excluded, our approach may be useful for a rapid assessment of the impacts of dams on riverine species when information is limited. With Brazil's current focus on economic development, reducing the impacts of hydroelectric projects on riverine dolphins is very challenging. Wherever feasible, relocation of proposed projects to areas with minimal impacts should always be considered. In addition, research is required on the level of, and how to mitigate, the impacts of dams in both the short and long term. 
The construction of dams may have contributed to the functional extinction of the baiji Lipotes vexillifer in the Yantze River (Turvey et al., 2007). The river dolphins of Brazil are not as threatened as those of Asia and thus much can still be learned from research on the effectiveness of mitigation measures. Such knowledge could also be beneficial to the conservation of threatened riverine cetaceans in Asia, for which such information is unlikely to be obtained in the near future.

\section{Acknowledgements}

C.C. Araújo is supported by a $\mathrm{PhD}$ scholarship from Coordenação de Aperfeiçoamento de Pessoal de Nível Superior, Brazil. The authors greatly appreciate the comments provided by Randall R. Reeves and Thomas A. Jefferson.

\section{References}

Agostinho, A.A., Pelicice, F.M. \& Gomes, L.C. (2008) Dams and the fish fauna of the Neotropical region: impacts and management related to diversity and fisheries. Brazilian Journal of Biology, 68, 1119-1132.

ANA (Agência Nacional de Águas) (2006) A região hidrográfica dos rios Tocantins e Araguaia. ANA, Brasília, DF, Brazil.

Aneel (Agência Nacional de Energia Elétrica) (2008) Atlas de energia elétrica do Brasil. ANEEL, Brasília, DF, Brazil.

Araújo, C.C. \& Da Silva, V.M.F. (2014) Spatial distribution of river dolphins, Inia geoffrensis (Iniidae) in the Araguaia River (central Brazil). Mammalia, in press.

ARAújo, C.C. \& WANG, J.Y. (2012) Botos (Inia geoffrensis) in the upper reaches of the Tocantins River (central Brazil) with observations of unusual behavior, including object carrying. Aquatic Mammals, $38,435-440$

Best, R.C. \& DA SiLVA, V.M.F. (1993) Inia geoffrensis. Mammalian Species, 426, 1-8.

Caughley, G. (1994) Directions in conservation biology. Journal of Animal Ecology, 63, 215-244.

Committee on TAxonomy (2014) List of marine mammal species and subspecies. Society of Marine Mammalogy. Http://www. marinemammalscience.org [accessed 4 February 2014].

Costa, A.F., Emin-Lima, R., Oliveira, L.R., Valiati, V., Silva Junior, J.S.E. \& Siciliano, S. (2013) How far does it go along the coast? Distribution and first genetic analyses of the boto (Inia geoffrensis) along the coast of Pará, Amazon, Brazil. Report of Scientific Committee Meeting of the International Whaling Commission, 65a, 1-12.

da Silva, C.R., Martins, A.C.M., Castro, I.J., Bernard, E., Cardoso, E.M., LIMA, D.S. et al. (2013) Mammals of Amapá State, eastern Brazilian Amazonia: a revised taxonomic list with comments on species distributions. Mammalia, 77 , 409-424.

Da Silva, V.M.F. (2011a) Tucuxi. In Plano de ação nacional para a conservação dos mamíferos aquáticos: pequenos cetáceos (eds C.C. Rocha-Campos, I.G. Câmara \& D.J. Pretto), pp. 21-23. Instituto Chico Mendes de Conservação da Biodiversidade, Brasília, Brazil.
Da Silva, V.M.F. (2011b) Boto-cor-de-rosa. In Plano de ação nacional para a conservação dos mamíferos aquáticos: pequenos cetáceos (eds C.C. Rocha-Campos, I.G. Câmara \& D.J. Pretto), pp. 17-20. Instituto Chico Mendes de Conservação da Biodiversidade, Brasília, Brazil.

DA Silva, V.M.F. \& Best, R.C. (1996) Sotalia fluviatilis. Mammalian Species, 527, 1-7.

da Silva, V.M.F., Fettuccia, D., Rodrigues, E. da S., Edwards, H., Moreno, I.B., Moura, J.F. et al. (2010) Report of the working group on distribution, habitat characteristics and preferences, and group size. Latin American Journal of Aquatic Mammals, 8, $31-38$.

DA Silva, V.M.F. \& Martin, A.R. (2010) Status, threats, conservation initiatives and possible solutions for Inia geoffrensis and Sotalia fluviatilis in Brazil. In The Action Plan for South American River Dolphins 2010-2020 (eds F. Trujillo, E. Crespo, P.A. Van Damme \& J.S. Usma), pp. 123-143. WWF, Fundación Omacha, Wildlife Conservation Society, Whale and Dolphin Conservation Society and Solamac. Bogotá, D.C., Colombia.

Hrbek, T., da Silva, V.M.F., Dutra, N., Gravena, W., Martin, A.R. \& Farias, I.P. (2014) A new species of river dolphin from Brazil or: how little do we know our biodiversity. PLOS ONE, 9(1), e83623.

IUCN (2013) The IUCN Red List of Threatened Species v. 2013.2. Http://www.iucnredlist.org [accessed 2 May 2013].

IWC (International Whaling Commission) (2000) Report of the Scientific Committee. 52nd Meeting of the International Whaling Commission, Adelaide, Australia.

Lima, D., Marmontel, M., Barbosa, D.A. \& Silva, C.R. (2010) Ocorrência de boto-vermelho (Inia geoffrensis) na bacia do rio Araguari, Amapá, Brasil. In XIV Reunião de Trabalhos de Especialistas em Mamíferos Aquáticos da América do Sul. SOLAMAC, Florianópolis, Brazil.

Lima, J.E.F.W., dos Santos, P.M.C., Carvalho, N.O. \& Da Silva, E.M. (2004) Diagnóstico do fluxo de sedimentos em suspensão na Bacia Araguaia-Tocantins. Embrapa Cerrados, ANEEL and ANA, Planaltina, Brasília, DF, Brazil.

Magrini, A., Fraga, I. \& Santos, M. (2000) Environmental management of watersheds in Brazil: a new approach to environmental and water resources management. In New Trends in Water and Environmental Engineering for Safety and Life (eds U. Maione, B. Mojone-Lehto \& R. Monti), pp. 1-7. Balkema, Rotterdam, Netherlands.

Martin, A.R., Da Silva, V.M.F. \& SAlmon, D.L. (2004) Riverine habitat preferences of botos (Inia geoffrensis) and tucuxis (Sotalia fluviatilis) in the central Amazon. Marine Mammal Science, 20, 189-200.

Mintzer, V.J., Martin, A.R., da Silva, V.M.F., Barbour, A.B., Lorenzen, K. \& Frazer, T.K. (2013) Effect of illegal harvest on apparent survival of Amazon River dolphins (Inia geoffrensis) Biological Conservation, 158, 280-286.

Mme (Ministério de Minas e Energia) (2007) Plano Nacional de Energia 203o/colaboração Empresa de Pesquisa Energética. MME/EPE, Brasília, DF, Brazil.

Mme (Ministério de Minas e Energia) (2013) Plano de Aceleração do Crescimento-PAC 2. MME, Brasília, DF, Brazil.

Myers, N., Mittermeier, R.A., Mittermeier, C.G., Fonseca, G.A.B. \& Kent, J. (2000) Biodiversity hotspots for conservation priorities. Nature, 403, 853-858.

Reeves, R.R. \& Leatherwood, S. (1994) Dams and river dolphins: can they co-exist? Ambio, 23, 172-175.

Reeves, R.R. \& S Sith, B.D. (1999) Interrupted migration and dispersal of river dolphins: some ecological effects of riverine development. In Proceedings of the Symposium on Animal 
Migration (eds UNEP/CMS), pp. 9-18. CMS Technical Series Publications no. 2, Bonn/The Hague and Gland, Switzerland.

Reeves, R.R., Smith, B.D. \& Kasuya, T. (eds) (2000) Biology and Conservation of Freshwater Cetaceans in Asia. Occasional papers of the IUCN Species Survival Commission no. 23, IUCN, Gland, Switzerland.

Siciliano, S., Emin-Lima, N.R., Costa, A.F., Rodrigues, A.L.F., Magalhães, F.A., Tosi, C.H. et al. (2008) Revisão do conhecimento sobre os mamíferos aquáticos da costa norte do Brasil. Arquivos do Museu Nacional, 66, 381-401.

Smith, B.D., Sinha, R.K., Kaiya, Z., Chaudhry, A.A., Renjun, L., DiNG, W. et al. (2000) Register of water development projects affecting Asian river cetaceans. In Biology and Conservation of Freshwater Cetaceans in Asia (eds R.R. Reeves, B.D. Smith \& T. Kasuya), pp. 22-39. Occasional papers of the IUCN Species Survival Commission no. 23, IUCN, Gland, Switzerland.
Trujillo, F., Crespo, E., Van Damme, P.A. \& Usma, J.S. (eds) (2010) The Action Plan for South America River Dolphins 2010-2020. WWF, Fundación Omacha, Wildlife Conservation Society, Whale and Dolphin Conservation Society and Solamac. Bogotá, D.C., Colombia.

Turvey, S.T., Pitman, R.L., Taylor, B.L., Barlow, J., Akamatsu, T., Barrett, L.A. et al. (2007) First human-caused extinction of a cetacean species? Biology Letters, 3, 537-540.

\section{Biographical sketches}

Claryana Araújo's research focuses on population dynamics and demography, extinction risks and the conservation of small cetaceans. JoHN WANG's research interests include taxonomy, ecology and the conservation of small cetaceans (particularly those in Asia), and ichthyology. 